\title{
Moisture Stability of Perovskite Solar Cells Processed in Supercritical Carbon Dioxide
}

\author{
Gilbert Annohene and Gary Tepper*
}

Department of Mechanical and Nuclear Engineering, Virginia Commonwealth University, Richmond, VA 23284, USA; annoheneg@vcu.edu

* Correspondence: gctepper@vcu.edu; Tel.: +1-804-827-4079

Citation: Annohene, G.; Tepper, G. Moisture Stability of Perovskite Solar Cells Processed in Supercritical Carbon Dioxide. Molecules 2021, 26 7570. https://doi.org/10.3390/ molecules 26247570

Academic Editor: Giuseppe Cirillo

Received: 30 November 2021 Accepted: 12 December 2021 Published: 14 December 2021

Publisher's Note: MDPI stays neutral with regard to jurisdictional claims in published maps and institutional affiliations.

Copyright: (c) 2021 by the authors. Licensee MDPI, Basel, Switzerland. This article is an open access article distributed under the terms and conditions of the Creative Commons Attribution (CC BY) license (https:// creativecommons.org/licenses/by/ $4.0 /)$.

\begin{abstract}
Performance degradation under environmental conditions currently limits the practical utility of perovskite-based solar cells. The moisture stability of $\mathrm{CH}_{3} \mathrm{NH}_{3} \mathrm{PbI}_{3}$ perovskite films and solar cells was measured during exposure to three different levels of relative humidity. The films were crystallized at two different temperatures with and without simultaneous exposure to supercritical carbon dioxide. The film crystallinity, optical absorption, and device photoconversion efficiency was measured over time for three relative humidity levels and both crystallization methods. It was determined that film crystallization in supercritical $\mathrm{CO}_{2}$ resulted in significant improvement in moisture stability for films processed at $50^{\circ} \mathrm{C}$, but negligible improvement in stability for films processed at $100^{\circ} \mathrm{C}$.
\end{abstract}

Keywords: perovskite; photovoltaics; supercritical carbon dioxide

\section{Introduction}

Perovskite-based solar cells have emerged as a potentially disruptive photovoltaic technology. Perovskite refers to the $\mathrm{ABX}_{3}$ crystal structure (usually $\mathrm{A}$ is organic ammonium such as methylammonium, $B$ is a cation such as lead, and $X$ is a halide such as chlorine, or mixed halides). Perovskites have been explored for application in light emitting diodes (LEDs) [1-3], low-power transistors [4-6], and highly efficient photodetectors [7-9]. Halide perovskite materials (inorganic, organic-inorganic) are of interest in the solar cell field due to their long charge carrier diffusion length, high light absorption coefficient, tunable bandgap, large extinction coefficient, relatively low material cost, solution-based processing, and excellent photoelectric conversion efficiency [10-19]. These advantages make halide perovskites an ideal material in the field of photovoltaics and other optoelectronic devices. The power conversion efficiency (PCE) of perovskite is comparable with crystalline silicon solar cells and has increased from $3.8 \%$ in 2009 [20] to a certified record of $25.5 \%$ in 2019 [21].

The crystallinity of the perovskite thin film is paramount to achieve optimum device performance. High-quality crystalline perovskite films with large grains produce superior optoelectronic performance because of a lower recombination rate and longer carrier diffusion length. Post-deposition annealing is used to enable short-range interdiffusion of the perovskite precursor compounds on the substrate to facilitate conversion into photoactive perovskite crystals [22-25]. However, thermal annealing can produce impurities and intermediate phases at high temperatures, and is problematic when scaling to large device areas since temperature variations produce inhomogeneities in film crystallinity [26-29].

We recently introduced the use of supercritical fluids (SCF) for post-deposition annealing of perovskites [30-32]. Supercritical carbon dioxide was shown to be an anti-solvent to $\mathrm{CH}_{3} \mathrm{NH}_{3} \mathrm{PbI}_{3}$ perovskite and facilitated low-temperature crystallization by reducing the energy barrier for molecular diffusion. Supercritical carbon dioxide $\left(\mathrm{scCO}_{2}\right)$ has a low critical point $\left(31.2^{\circ} \mathrm{C}, 7.38 \mathrm{Mpa}\right.$ or $\left.1070.4 \mathrm{psi}\right)$, no surface tension, liquid-like density, gas-like viscosity, and diffusivity and negligible solubility to the perovskite films. Trace amounts (less than $2 \%$ ) of organic co-solvents could be added to the $\mathrm{scCO}_{2}$ to modify the 
solubility and produce various film morphologies and crystal orientations [31]. We have also reported the photovoltaic performance of $\mathrm{CH}_{3} \mathrm{NH}_{3} \mathrm{PbI}_{3}$ perovskite solar cells where the photoactive layer was annealed in $\mathrm{scCO}_{2}$ at $50{ }^{\circ} \mathrm{C}$ and achieved a PCE of $17.22 \%$ [32].

Although the photovoltaic performance of PSCs is outstanding, its major challenge to commercialization remains the stability of the crystals $[33,34]$ under environmental conditions. Poor stability of PSCs is primarily due to degradation of the perovskite crystals and can be caused by many factors such as exposure to atmospheric oxygen and humidity [35-38], high temperature [39], illumination [40,41], and ion migration [42,43]. However, degradation by humidity remains the dominant factor reducing the stability of the perovskite materials. Several approaches have been adopted to stabilize halide perovskites, including compositional tuning [44-46], low dimensional perovskites [47,48], additives [49,50], use of a surface blocking layer [41,51,52], and enhancing the grain size.

For hybrid organic-inorganic perovskites, instability is due to the organic component, where the $\mathrm{CH}_{3} \mathrm{NH}_{3} \mathrm{PbI}_{3}$ decomposes into a lead iodide $\left(\mathrm{PbI}_{2}\right)$ and methylammonium iodide $\left(\mathrm{CH}_{3} \mathrm{NH}_{3} \mathrm{I}\right)$. $\mathrm{CH}_{3} \mathrm{NH}_{3} \mathrm{I}$ gives up a proton to water, forming $\mathrm{H}_{3} \mathrm{O}^{+}$by breaking the bond between the $\mathrm{A}$ and $\mathrm{B}$ molecules of the $\mathrm{ABX}_{3}$ perovskite structure [53-55]. Frost et al. explained a possible water-facilitated decomposition path shown in Equations (1)-(4) [56]. Exposure of the perovskite to moisture results in the organic iodide forming $\mathrm{HI}$ acid, which dissolves in water. Trace amounts of water are adequate to deprotonate the organic component to cause degradation. In addition, the exposure of the film to trace amounts of $\mathrm{H}_{2} \mathrm{O}$ results in partial decomposition until the byproducts reach equilibrium.

$$
\begin{aligned}
& \mathrm{CH}_{3} \mathrm{NH}_{3} \mathrm{PbI}_{3}(\mathrm{~s}) \leftrightarrow \mathrm{CH}_{3} \mathrm{NH}_{3} \mathrm{I}(\mathrm{aq})+\mathrm{PbI}_{2}(\mathrm{~s}) \\
& \mathrm{CH}_{3} \mathrm{NH}_{3} \mathrm{I}(\mathrm{aq}) \leftrightarrow \mathrm{CH}_{3} \mathrm{NH}_{2}(\mathrm{aq})+\mathrm{HI}(\mathrm{aq}) \\
& 4 \mathrm{HI}(\mathrm{aq})+\mathrm{O}_{2} \leftrightarrow 2 \mathrm{I}_{2}(\mathrm{~s})+2 \mathrm{H}_{2} \mathrm{O} \\
& 2 \mathrm{HI}(\mathrm{aq}) \leftrightarrow \mathrm{H}_{2}+\mathrm{I}_{2}(\mathrm{~s})
\end{aligned}
$$

In our initial studies, we demonstrated that annealing $\mathrm{CH}_{3} \mathrm{NH}_{3} \mathrm{PbI}_{3}$ perovskite thin films at low temperature in $\mathrm{scCO}_{2}$ resulted in high-quality films and devices with corresponding high photovoltaic efficiencies. In this paper, we investigate the humidity degradation rate of films and photovoltaic devices processed in $\mathrm{scCO}_{2}$. The effect of three levels of relative humidity ( $\mathrm{RH}$ ) (No exposure $(<5 \% \mathrm{RH}), 40 \% \mathrm{RH}$, and $60 \% \mathrm{RH}$ ) on perovskite film optical absorption, crystallinity and resulting device photo conversion efficiency (PCE) was measured for films processed in $\mathrm{scCO}_{2}$ in comparison to films annealed without $\mathrm{scCO}_{2}$.

\section{Methods}

\subsection{Device Fabrication}

All film and device fabrication procedures were reported previously [32]. Fluorinedoped tin oxide (FTO) glass substrates (Ossila, TEC 15, Sheffield, UK) of size $25 \mathrm{~mm}$ by $25 \mathrm{~mm}$ were used. The substrate was cleaned as follows; ultrasonic bath in $2 \%$ Hellmanex solution, rinse with deionized water, ultrasonic bath in isopropanol for $15 \mathrm{~min}$, ultrasonic bath in acetone for $15 \mathrm{~min}$, rinse acetone and isopropanol, dry the isopropanol with dry air and plasma cleaned for $15 \mathrm{~min}$.

The titanium dioxide $\left(\mathrm{TiO}_{2}\right)$ blocking layer $\left(\mathrm{bl}-\mathrm{TiO}_{2}\right)$ was formed by spin coating $0.15 \mathrm{M}$ titanium diisopropoxide dis(acetylacetonate) (Sigma-Aldrich, $75 \mathrm{wt} \%$ in isopropanol) in 1-butanol (anhydrous, Sigma-Aldrich, 99.8\%) onto the FTO glass substrate at $700 \mathrm{rpm}$ for $8 \mathrm{~s}, 1000 \mathrm{rpm}$ for $10 \mathrm{~s}$ and $2000 \mathrm{rpm}$ for $40 \mathrm{~s}$, followed by drying at $125^{\circ} \mathrm{C}$ for $5 \mathrm{~min}[32,57]$. The mesoporous TiO_2 $\left(\mathrm{mp}-\mathrm{TiO}_{2}\right)$ layer was deposited on the bl- $\mathrm{TiO}_{2}$ by spin-coating a $\mathrm{TiO}_{2}$ colloidal solution containing $0.6 \mathrm{~g}$ of $\mathrm{TiO}_{2}$ paste (30NR-D, Greatcell Solar) diluted in $5 \mathrm{~mL}$ of anhydrous ethanol solution at $2000 \mathrm{rpm}$ for $20 \mathrm{~s}$, followed by annealing at $540{ }^{\circ} \mathrm{C}$ for $1 \mathrm{~h}$. The substrate was further treated with $20 \mathrm{mM}$ aqueous $\mathrm{TiCl}_{4}(>98 \%$, Sigma-Aldrich, 
Saint Louis, MO, USA) solution at $90{ }^{\circ} \mathrm{C}$ for $10 \mathrm{~min}$, cleaned with deionized water and then sintered at $500{ }^{\circ} \mathrm{C}$ for $30 \mathrm{~min}[32,57]$.

$\mathrm{CH}_{3} \mathrm{NH}_{3} \mathrm{PbI}_{3}$ was synthesized by mixing a 1:1:1 molar ratio of $2.385 \mathrm{~g}$ of methyl ammonium iodide $\left(\mathrm{CH}_{3} \mathrm{NH}_{3} \mathrm{I}\right)$ (98\%, Sigma Aldrich), $6.915 \mathrm{~g}$ of lead (II) iodide $\left(\mathrm{PbI}_{2}\right)$ (99.9985\%, Alfa Aesar, Ward Hill, MA, USA), and $1.063 \mathrm{~mL}$ of dimethyl sulfoxide (DMSO) ( $\geq 99.9 \%$, anhydrous, Sigma Aldrich) in $9.484 \mathrm{~mL}$ of $\mathrm{N}, \mathrm{N}-$ dimethylformamide (DMF) ( $\geq 99.8 \%$, anhydrous, Sigma Aldrich) and $0.3 \mathrm{~mL}$ of diethyl ether $(\geq 99.8 \%$ anhydrous, Sigma Aldrich). The solution was stirred for $1 \mathrm{~h}$ at room temperature and filtered with $0.2 \mu \mathrm{m}$ syringe filter (Corning Inc., Corning, NY, USA). The solution was processed in an argon-filled glove box. The precursor solution was spin coated onto the substrate at $6000 \mathrm{rpm}$ for $25 \mathrm{~s}$. and $0.5 \mathrm{~mL}$ of diethyl ether was dripped onto the rotating surface $6 \mathrm{~s}$ into the spinning. For thermal annealed films, the substrate was placed on a hotplate at either 50 or $100{ }^{\circ} \mathrm{C}$ for $30 \mathrm{~min}$. For $\mathrm{scCO}_{2}$ annealed films, the thin film was placed in a pressure vessel (Parr Instrument Pressure Reactor 4768) and a syringe pump (Teledyne ISCO Pump 260D) was used to pressurize the carbon dioxide at $1300 \mathrm{psi}$ and $50{ }^{\circ} \mathrm{C}$ for $30 \mathrm{~min}$. The substrates were then removed and blown with argon and dried in the glovebox [30-32].

A total of $65 \mu \mathrm{L}$ of spiro-MeOTAD solution, which contained $72.3 \mathrm{mg}$ spiro-MeOTAD (Sublimed, Ossila), $28.8 \mu \mathrm{L}$ of 4-tert-butyl pyridine (Ossila), and $17.5 \mu \mathrm{L}$ of lithium bis (trifluoromethanesulfonyl)imide (Li-TFSI) solution (520 mg Li-TSFI (Ossila) in $1 \mathrm{~mL}$ acetonitrile (Sigma-Aldrich, 99.8\%) in $1 \mathrm{ml}$ of chlorobenzene was spin-coated on the perovskite layer at $3000 \mathrm{rpm}$ for $30 \mathrm{~s}$ [58,59]. Finally, the Silver (Ag) electrode was deposited using electron beam evaporation at a constant evaporation rate of $0.03 \mathrm{~nm} / \mathrm{s}$ through a shadow mask resulting in an electrode thickness of approximately $100 \mathrm{~nm}$. Home-made humidity chambers were used to expose the samples to the higher relative humidity levels (40 and $60 \%)$. For lower relative humidity $(<5 \% \mathrm{RH})$, samples were placed in a dry desiccator kept in an argon filled glovebox.

\subsection{Device Characterization}

The crystallographic properties of the perovskite films were characterized by X-ray diffraction (XRD) measurements (PANalytical MPD X'pert Pro) using a Cu K $\alpha(\lambda=1.54 \mathrm{~nm})$ radiation source that operated at $45 \mathrm{kV}$ and $40 \mathrm{~mA}$. The X-ray diffractograms were obtained at a scan rate of $0.01^{\circ} \mathrm{s}^{-1}$ for $2 \theta$ values between $10^{\circ}$ and $60^{\circ}$. The surface coverage and grain size were obtained using a scanning electron microscope (SEM) (Hitachi SU-70 FESEM) at $20 \mathrm{kV}$, and analyzed using an ImageJ software package. Optical spectrometry (transmission, reflection, absorption) of the films was conducted using a spectral response measurement system (PerkinElmer Lambda 35 UV/VIS Spectrometer). The J-V curves were measured using a G2V optics small area Pico simulator at room temperature under AM 1.5 G illuminations $\left(100 \mathrm{~mW} / \mathrm{cm}^{2}\right)$, and calibrated using a standard silicon solar cell device. An aperture mask of $0.09 \mathrm{~cm}^{2}$ was used to define the device area.

\section{Results and Discussion}

In our previous studies, we reported the effect of $\mathrm{scCO}_{2}$ annealing on the crystallinity and photovoltaic performance of perovskite devices [30-32]. The crystal structure was monitored using XRD and the diffraction peaks at $14.4^{\circ}, 24.8^{\circ}, 28.7^{\circ}$, and $32.2^{\circ}$ correspond to the (110), (202), (220), and (310) planes of crystalline $\mathrm{CH}_{3} \mathrm{NH}_{3} \mathrm{PbI}_{3}$, respectively, with a tetragonal crystal structure [60-63]. The XRD pattern for $\mathrm{PbI}_{2}$ shows that, in general, thin film growth is oriented along the (001) direction at $12.73^{\circ}$ irrespective of the spin parameters. This is typically due to the use of DMF, a less soluble, polar solvent containing electronegative oxygen atoms [64]. The presence of $\mathrm{PbI}_{2}$ typically indicates incomplete crystallization and/or degradation [65]. The effect of relative humidity on the $\mathrm{CH}_{3} \mathrm{NH}_{3} \mathrm{PbI}_{3}$ crystallinity was studied using XRD and UV-VIS.

Figure 1, part $\mathrm{A}$, shows the normalized amplitude ratio of the dominant $\mathrm{PbI}_{2}$ peak at (001) versus that of $\mathrm{CH}_{3} \mathrm{NH}_{3} \mathrm{PbI}_{3}$ (110) over 25 days after thermal annealing alone at $50{ }^{\circ} \mathrm{C}$. An increase in this ratio is used as a measure of film degradation. Negligible 
degradation was observed in samples kept in a low humidity environment due to less moisture interactions with the perovskite film. However, when the samples were exposed to a relative humidity of $40 \%$, there is an exponential decay beginning on about day 15 . Exposing the thin films to $60 \% \mathrm{RH}$ also shows rapid exponential degradation but beginning on the first day of exposure. Therefore, we observe an extremely strong correlation between an increase in relative humidity with degradation of the perovskite film.
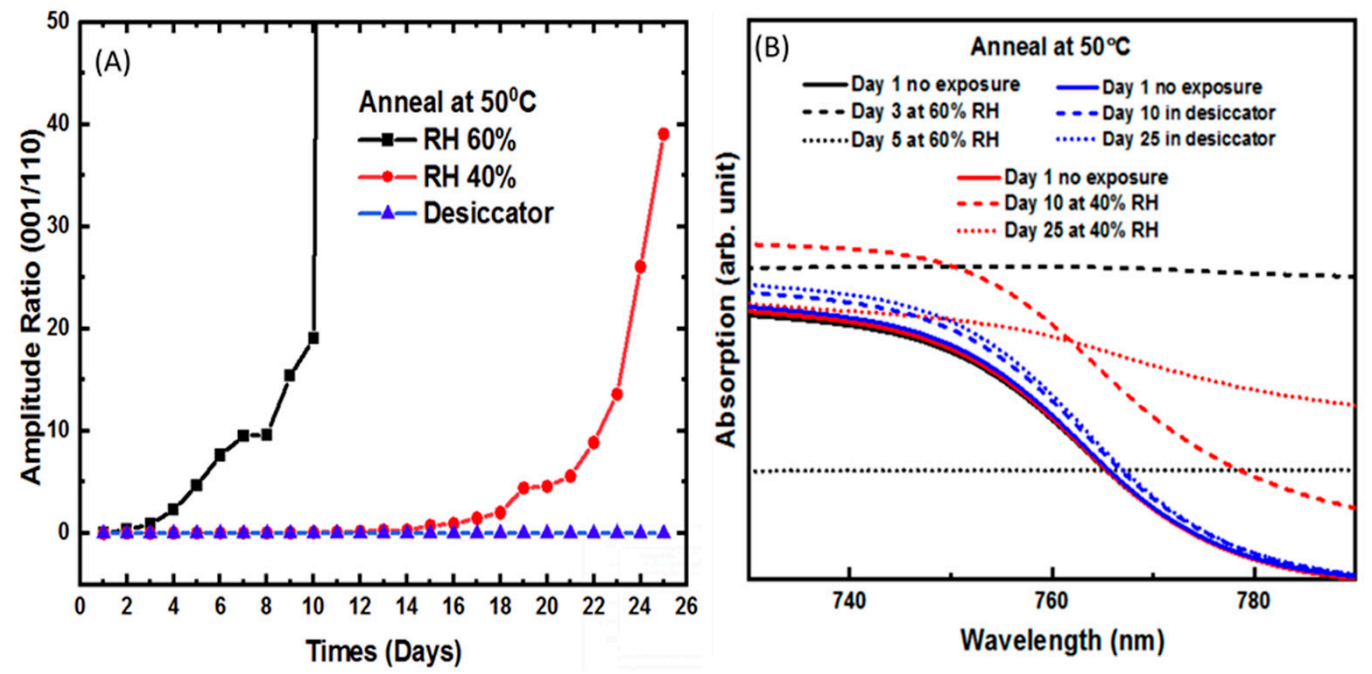

Figure 1. (A)Amplitude ratio of relative intensity of the (001) and (110) planes of $\mathrm{CH}_{3} \mathrm{NH}_{3} \mathrm{PbI}_{3}$ of films thermally annealed at $50{ }^{\circ} \mathrm{C}$ without $\mathrm{scCO}_{2}$. (B) Optical absorption spectra of the film at different humidity parameters corresponding to (A).

Figure 1, part B, shows the optical absorption spectra of the perovskite film annealed at $50{ }^{\circ} \mathrm{C}$ at three different days for each relative humidity level. The absorption data is presented over a range of wavelengths near the perovskite band edge to try to understand the impact of moisture exposure on band-to-band transitions. Moisture damage will result in a loss of crystallinity and corresponding band structure. We, therefore, focus our attention on the shape of the band edge rather than the absorption intensity since the latter includes other factors such as film thickness and surface roughness, which were not independently measured. The low humidity sample shows very little change over time. However, at $40 \% \mathrm{RH}$, the spectrum begins to change on day ten and shows very little band edge by day 25 . At $60 \% \mathrm{RH}$, the band edge disappears immediately leading to a featureless absorption spectra and by day five, we see no absorption spectra response.

Figure 2, part $\mathrm{A}$, shows the amplitude ratio of the $\mathrm{PbI}_{2}$ (001) peak to that of the $\mathrm{CH}_{3} \mathrm{NH}_{3} \mathrm{PbI}_{3}(110)$ peak versus time and at three different humidity levels for a sample annealed at $100{ }^{\circ} \mathrm{C}$ without $\mathrm{scCO}_{2}$. No degradation was observed for samples kept at low humidity. At $40 \%$ RH, no crystal degradation was observed until day 15 , where the peak begins to increase slowly. At 60\% RH, rapid, exponential degradation was observed beginning on day three. The slower degradation rate of films annealed at $100{ }^{\circ} \mathrm{C}$ compared to those annealed at $50{ }^{\circ} \mathrm{C}$ is likely due to the higher initial film quality and crystallinity in the films annealed at the higher temperature, as we reported previously.

Figure 2, part B, shows the optical absorption spectra of the perovskite film annealed at $100{ }^{\circ} \mathrm{C}$ without $\mathrm{scCO}_{2}$ at three different relative humidity levels. The absorption spectra for the dry sample remained unchanged after 25 days. At $40 \% \mathrm{RH}$, the absorption band edge is still clearly visible on day ten, but is significantly degraded by day 25 . At $60 \% \mathrm{RH}$, the absorption band edge is almost entirely gone by day three and disappears entirely by day 5. This data confirms that traditional annealing at either 50 or $100^{\circ} \mathrm{C}$ does not offer any significant protection against humidity degradation even though the films annealed at the higher temperature perform slightly better due to the superior initial crystallinity. 

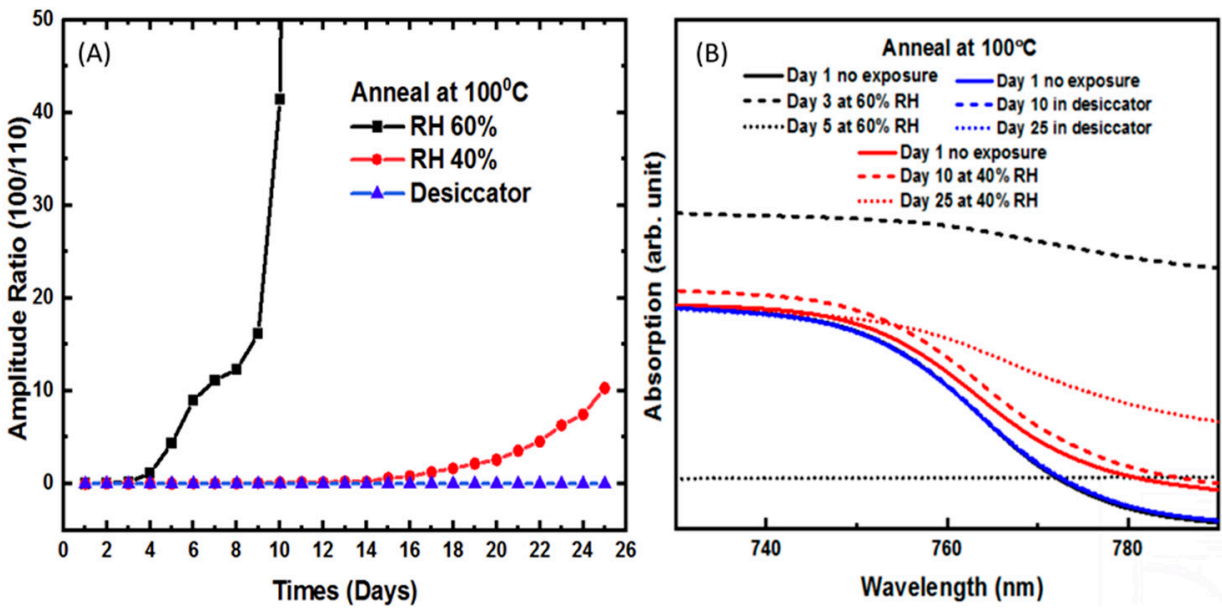

Figure 2. (A) Amplitude ratio of relative intensity of the (001) and (110) planes of $\mathrm{CH}_{3} \mathrm{NH}_{3} \mathrm{PbI}_{3}$ of films thermally annealed at $100{ }^{\circ} \mathrm{C}$ without $\mathrm{scCO}_{2}$ (B) Optical absorption spectra of the film at different humidity parameters corresponding to (A).

Figure 3, part A, is a plot of the relative peak amplitude versus time for the sample processed in $\mathrm{ScCO}_{2}$ at $50{ }^{\circ} \mathrm{C}$ at three different humidity levels. Negligible degradation was observed at the low humidity level. At $40 \% \mathrm{RH}$, degradation begins on the 15th day and increases slowly. At $60 \% \mathrm{RH}$, rapid exponential degradation was observed beginning on the first day of exposure, indicating that film degradation began immediately at this higher humidity level. After day nine, the absorption ratio plateaus and then decreases. We attribute this behavior to the very high level of film degradation. That is, after day nine, the crystal structure has been severely compromised and the X-ray diffraction data has little value.


Figure 3. (A) Amplitude ratio of relative intensity of the (001) and (110) planes of $\mathrm{CH}_{3} \mathrm{NH}_{3} \mathrm{PbI}_{3}$ of films annealing at $50{ }^{\circ} \mathrm{C}$ in $\mathrm{scCO}_{2}$. (B) Optical absorption spectra of the film at different humidity parameters corresponding to $(\mathbf{A})$.

Figure 3, part B, shows the optical absorption spectra of perovskite films processed in $\mathrm{scCO}_{2}$ at $50{ }^{\circ} \mathrm{C}$ and at three different humidity levels. The absorption spectra for the dry samples remains unchanged through the 25th day. At $40 \% \mathrm{RH}$, the band edge begins to change by day ten and is not discernable by day 25 . At $60 \% \mathrm{RH}$, the band edge disappears completely by day three with no visible structure in the absorption spectra.

Figure 4 compares the power conversion efficiency versus time for films thermally annealed at $50{ }^{\circ} \mathrm{C}$ with (B) and without (A) $\mathrm{scCO}_{2}$ at three different relative humidity levels. Multiple photovoltaic devices were produced from each sample using a pixelated 
shadow mask to deposit the silver contacts. PCE data was obtained from each device and the error bars presented in Figures 4 and 5 represent the precision intervals of the data. On day one (no humidity exposure), the average PCE of devices where the perovskite layer was annealed with $\mathrm{scCO}_{2}$ was about twice that of devices where the perovskite layer was annealed without $\mathrm{scCO}_{2}$. Specifically, devices where the perovskite layer was annealed at $50{ }^{\circ} \mathrm{C}$ had a PCE of $6.29 \pm 1.72 \%, 6.12 \pm 1.77 \%$, and $5.46 \pm 0.87 \%$. However, devices where the perovskite layer was annealed at the same temperature, but in $\mathrm{scCO}_{2}$, had a PCE of $14.27 \pm 1.09 \%, 13.07 \pm 0.90 \%$, and $14.52 \pm 1.32 \%$, respectively. This shows that perovskite films annealed in the presence of $\mathrm{scCO}_{2}$ exhibit much better photovoltaic performance at these lower temperatures due to superior film quality.
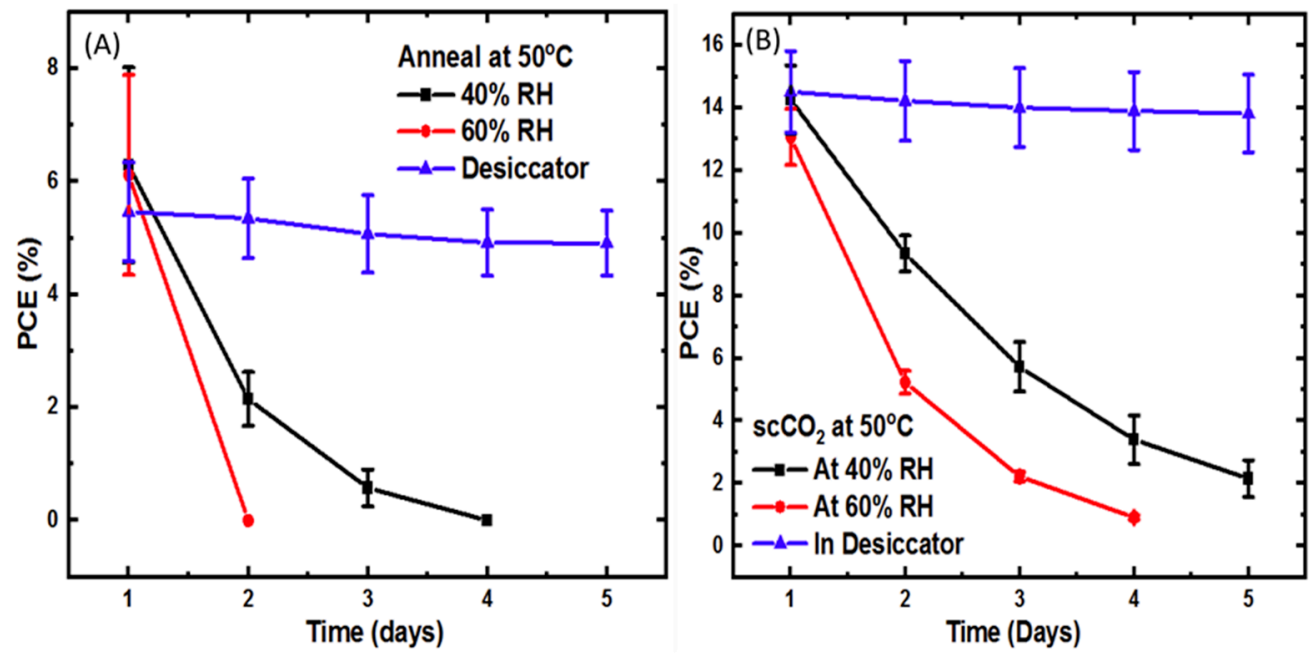

Figure 4. PCE versus time for perovskite films (A) annealed at $50{ }^{\circ} \mathrm{C}$ without $\mathrm{scCO}_{2}$ and (B) annealed at $50{ }^{\circ} \mathrm{C}$ in $\mathrm{scCO}_{2}$.
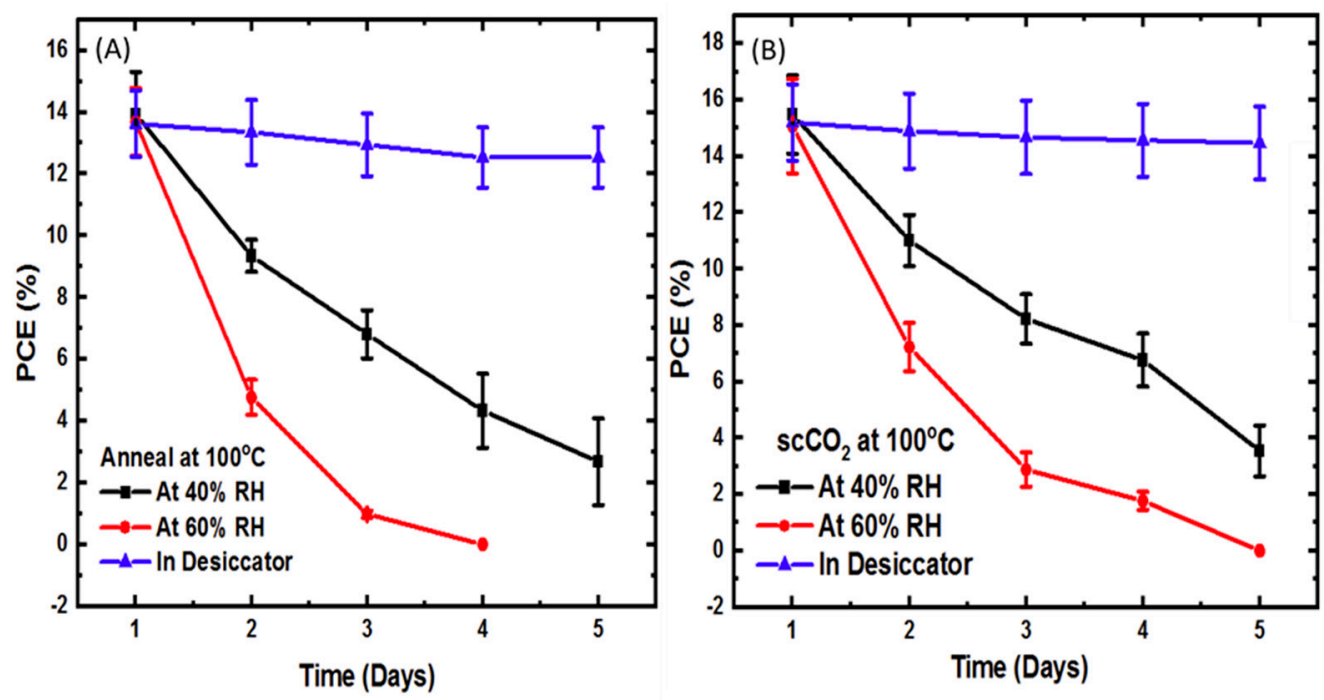

Figure 5. PCE degradation rate of perovskite films after annealing (A) at $100{ }^{\circ} \mathrm{C}$ without $\mathrm{scCO}_{2}$ and (B) at $100{ }^{\circ} \mathrm{C}$ with $\mathrm{scCO}_{2}$.

When the devices are kept in a dry desiccator, the PCE remains relatively constant, as would be expected. Upon exposure to RH levels of 40 and $60 \%$, both sets of devices show a decrease in PCE with time, but the devices annealed in $\mathrm{scCO}_{2}$ exhibit a slower rate of degradation. Thus, perovskite films annealed in the presence of $\mathrm{scCO}_{2}$ at low temperatures not only exhibit superior film quality (greater smoothness, larger grain) and higher crystallinity, but also higher photovoltaic efficiency and a slower degradation 
rate upon exposure to humidity compared to films thermally annealed in the absence of $\mathrm{scCO}_{2}$ [30-32].

Figure 5 compares the power conversion efficiency versus time of devices, where the perovskite layer was thermally annealed at $100{ }^{\circ} \mathrm{C}$ with and without $\mathrm{scCO}_{2}$ and at three different relative humidity levels. At this higher temperature, the initial PCE and degradation rate at each $\mathrm{RH}$ level was approximately the same for devices annealed in $\mathrm{scCO}_{2}$ and devices annealed without $\mathrm{scCO}_{2}$. Therefore, we see no significant benefit in using $\mathrm{scCO}_{2}$ for annealing perovskite films at higher temperatures.

Comparing the photoconversion efficiency data of Figures 4 and 5 to the X-ray and optical absorption data of Figures 1-3 shows similar trends, but much different sensitivity. That is, the drop in observed device efficiency is consistent with the degradation in crystal structure and band structure, but is a much more sensitive indicator. For example, if we consider the films processed at $50{ }^{\circ} \mathrm{C}$ in supercritical $\mathrm{CO}_{2}$, the data of Figure 3, part A, at $40 \% \mathrm{RH}$ shows the amplitude ratio increasing on day 14 . However, the PCE data of Figure 4, part B, for devices constructed from these same films shows a sudden drop in PCE from $14 \%$ on day one to $9 \%$ on day two and down to $2 \%$ by day five. We conclude from this that device efficiency is a much more sensitive indicator of moisture degradation than either crystallographic or optical absorption measurements.

\section{Conclusions}

The influence of humidity on the rate of $\mathrm{CH}_{3} \mathrm{NH}_{3} \mathrm{PbI}_{3}$ perovskite film degradation was measured for films processed in supercritical $\mathrm{CO}_{2}$ at 50 and $100{ }^{\circ} \mathrm{C}$ in comparison to films annealed at the same temperatures but without supercritical $\mathrm{CO}_{2}$. The film quality over 25 days was measured for three different relative humidity levels using $\mathrm{X}$-ray diffraction, optical absorption, and device photoconversion efficiency. For devices processed at $50{ }^{\circ} \mathrm{C}$, it was determined that supercritical $\mathrm{CO}_{2}$ increases both the initial film quality as well as the resistance to humidity degradation and results in devices with higher photoconversion efficiency and a lower rate of performance degradation. For devices processed at $100{ }^{\circ} \mathrm{C}$, no significant improvement in film quality, photoconversion efficiency or humidity resistance was observed for films processed in supercritical $\mathrm{CO}_{2}$.

Author Contributions: Conceptualization, G.A. and G.T.; Methodology, G.A. and G.T.; Formal analysis, G.A. and G.T.; Investigation, G.A. and G.T.; Resources, G.T.; Data curation, G.A.; Writing—original draft preparation, G.A.; Writing-review and editing, G.T.; Supervision, G.T.; Project administration, G.T.; Funding acquisition, G.T. All authors have read and agreed to the published version of the manuscript.

Funding: This research received no external funding.

Institutional Review Board Statement: Not applicable.

Informed Consent Statement: Not applicable.

Data Availability Statement: The data presented in this study are available on request from the corresponding author.

Acknowledgments: This work was supported by a grant from the VCU Innovation Gateway. The Nanomaterials Core Characterization Facility at VCU helped in all of the material characterizations.

Conflicts of Interest: The authors declare no conflict of interest.

Sample Availability: Samples of the compounds "perovskite films and devices" are available from the authors.

\section{References}

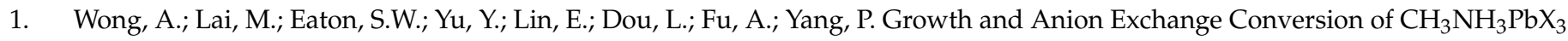
Nanorod Arrays for Light-Emitting Diodes. Nano Lett. 2015, 15, 5519-5524. [CrossRef] [PubMed]

2. Leyden, M.R.; Meng, L.; Jiang, Y.; Ono, L.K.; Qiu, L.; Juarez-Perez, E.J.; Qin, C.; Adachi, C.; Qi, Y. Methylammonium Lead Bromide Perovskite Light-Emitting Diodes by Chemical Vapor Deposition. J. Phys. Chem. Lett. 2017, 8, 3193-3198. [CrossRef] 
3. Yuan, S.; Wang, Z.-K.; Zhuo, M.-P.; Tian, Q.-S.; Jin, Y.; Liao, L.-S. Self-Assembled High Quality CsPbBr 3 Quantum Dot Films toward Highly Efficient Light-Emitting Diodes. ACS Nano 2018, 12, 9541-9548. [CrossRef] [PubMed]

4. Senanayak, S.P.; Yang, B.; Thomas, T.H.; Giesbrecht, N.; Huang, W.; Gann, E.; Nair, B.; Gödel, K.; Guha, S.; Moya, X.; et al. Understanding charge transport in lead iodide perovskite thin-film field-effect transistors. Sci. Adv. 2017, 3, e1601935. [CrossRef]

5. Lin, Y.; Pattanasattayavong, P.; Anthopoulos, T.D. Metal-Halide Perovskite Transistors for Printed Electronics: Challenges and Opportunities. Adv. Mater. 2017, 29, 1702838. [CrossRef] [PubMed]

6. $\quad$ Li, D.; Cheng, H.; Wang, Y.; Zhao, Z.; Wang, G.; Wu, H.; He, Q.; Huang, Y.; Duan, X. The Effect of Thermal Annealing on Charge Transport in Organolead Halide Perovskite Microplate Field-Effect Transistors. Adv. Mater. 2017, 29, 1601959. [CrossRef]

7. Hu, X.; Zhang, X.; Liang, L.; Bao, J.; Li, S.; Yang, W.; Xie, Y. High-Performance Flexible Broadband Photodetector Based on Organolead Halide Perovskite. Adv. Funct. Mater. 2014, 24, 7373-7380. [CrossRef]

8. Lan, C.; Dong, R.; Zhou, Z.; Shu, L.; Li, D.; Yip, S.; Ho, J.C. Large-scale synthesis of freestanding layer-structured PbI 2 and $\mathrm{MAPbI}_{3}$ nanosheets for high-performance photodetection. Adv. Mater. 2017, 29, 1702759. [CrossRef] [PubMed]

9. Ji, L.; Hsu, H.-Y.; Lee, J.C.; Bard, A.J.; Yu, E.T. High-Performance Photodetectors Based on Solution-Processed Epitaxial Grown Hybrid Halide Perovskites. Nano Lett. 2018, 18, 994-1000. [CrossRef]

10. Snaith, H.J. Perovskites: The Emergence of a New Era for Low-Cost, High-Efficiency Solar Cells. J. Phys. Chem. Lett. 2013, 4, 3623-3630. [CrossRef]

11. Stranks, S.D.; Eperon, G.E.; Grancini, G.; Menelaou, C.; Alcocer, M.J.P.; Leijtens, T.; Herz, L.M.; Petrozza, A.; Snaith, H.J. ElectronHole Diffusion Lengths Exceeding 1 Micrometer in an Organometal Trihalide Perovskite Absorber. Science 2013, 342, 341-344. [CrossRef]

12. De Wolf, S.; Holovsky, J.; Moon, S.-J.; Löper, P.; Niesen, B.; Ledinsky, M.; Haug, F.-J.; Yum, J.-H.; Ballif, C. Organometallic Halide Perovskites: Sharp Optical Absorption Edge and Its Relation to Photovoltaic Performance. J. Phys. Chem. Lett. 2014, 5, 1035-1039. [CrossRef]

13. Unger, E.L.; Kegelmann, L.; Suchan, K.; Sörell, D.; Korte, L.; Albrecht, S. Correction: Roadmap and roadblocks for the band gap tunability of metal halide perovskites. J. Mater. Chem. A 2017, 5, 15983. [CrossRef]

14. Sutton, R.J.; Eperon, G.E.; Miranda, L.; Parrott, E.S.; Kamino, B.A.; Patel, J.B.; Hörantner, M.T.; Johnston, M.B.; Haghighirad, A.A.; Moore, D.T.; et al. Bandgap-Tunable Cesium Lead Halide Perovskites with High Thermal Stability for Efficient Solar Cells. Adv. Energy Mater. 2016, 6, 1502458. [CrossRef]

15. Shi, D.; Adinolfi, V.; Comin, R.; Yuan, M.; Alarousu, E.; Buin, A.; Chen, Y.; Hoogland, S.; Rothenberger, A.; Katsiev, K.; et al. Low trap-state density and long carrier diffusion in organolead trihalide perovskite single crystals. Science 2015, 347, 519-522. [CrossRef]

16. Dong, Q.; Fang, Y.; Shao, Y.; Mulligan, P.; Qiu, J.; Cao, L.; Huang, J. Electron-hole diffusion lengths >175 $\mu \mathrm{m}$ in solution-grown $\mathrm{CH}_{3} \mathrm{NH}_{3} \mathrm{PbI}_{3}$ single crystals. Science 2015, 347, 967-970. [CrossRef]

17. Chen, H.; Ye, F.; Tang, W.; He, J.; Yin, M.; Wang, Y.; Xie, F.; Bi, E.; Yang, X.; Grätzel, M.; et al. A solvent- and vacuum-free route to large-area perovskite films for efficient solar modules. Nature 2017, 550, 92-95. [CrossRef]

18. Chen, Z.; Dong, Q.; Liu, Y.; Bao, C.; Fang, Y.; Lin, Y.; Tang, S.; Wang, Q.; Xiao, X.; Bai, Y.; et al. Thin single crystal perovskite solar cells to harvest below-bandgap light absorption. Nat. Commun. 2017, 8, 1890. [CrossRef]

19. Ergen, O.; Gilbert, S.M.; Pham, T.; Turner, S.J.; Tan, M.T.Z.; Worsley, M.A.; Zettl, A. Graded bandgap perovskite solar cells. Nat. Mater. 2017, 16, 522-525. [CrossRef]

20. Kojima, A.; Teshima, K.; Shirai, Y.; Miyasaka, T. Organometal Halide Perovskites as Visible-Light Sensitizers for Photovoltaic Cells. J. Am. Chem. Soc. 2009, 131, 6050-6051. [CrossRef]

21. National Renewable Energy Laboratory. Best Research-Cell Efficiency Chart. 2019. Available online: https://www.nrel.gov/pv / cell-efficiency.html (accessed on 11 December 2021).

22. Xiao, Z.; Dong, Q.; Bi, C.; Shao, Y.; Yuan, Y.; Huang, J. Solvent Annealing of Perovskite-Induced Crystal Growth for PhotovoltaicDevice Efficiency Enhancement. Adv. Mater. 2014, 26, 6503-6509. [CrossRef] [PubMed]

23. Zhang, W.; Pathak, S.; Sakai, N.; Stergiopoulos, T.; Nayak, P.K.; Noel, N.K.; Haghighirad, A.A.; Burlakov, V.M.; Dequilettes, D.W.; Sadhanala, A.; et al. Enhanced optoelectronic quality of perovskite thin films with hypophosphorous acid for planar heterojunction solar cells. Nat. Commun. 2015, 6, 10030. [CrossRef]

24. Wu, C.-G.; Chiang, C.-H.; Tseng, Z.-L.; Nazeeruddin, K.; Hagfeldt, A.; Grätzel, M. High efficiency stable inverted perovskite solar cells without current hysteresis. Energy Environ. Sci. 2015, 8, 2725-2733. [CrossRef]

25. Bi, C.; Wang, Q.; Shao, Y.; Yuan, Y.; Xiao, Z.; Huang, J. Non-wetting surface-driven high-aspect-ratio crystalline grain growth for efficient hybrid perovskite solar cells. Nat. Commun. 2015, 6, 7747. [CrossRef]

26. Eperon, G.E.; Burlakov, V.M.; Docampo, P.; Goriely, A.; Snaith, H.J. Morphological Control for High Performance, SolutionProcessed Planar Heterojunction Perovskite Solar Cells. Adv. Funct. Mater. 2013, 24, 151-157. [CrossRef]

27. Shi, S.; Li, Y.; Li, X.; Wang, H. Advancements in all-solid-state hybrid solar cells based on organometal halide perovskites. Mater. Horiz. 2015, 2, 378-405. [CrossRef]

28. Jiang, Y.; Wu, C.; Li, L.; Wang, K.; Tao, Z.; Gao, F.; Cheng, W.; Cheng, J.; Zhao, X.-Y.; Priya, S.; et al. All electrospray printed perovskite solar cells. Nano Energy 2018, 53, 440-448. [CrossRef]

29. Cao, Q.; Yang, S.; Gao, Q.; Lei, L.; Yu, Y.; Shao, J.; Liu, Y. Fast and Controllable Crystallization of Perovskite Films by Microwave Irradiation Process. ACS Appl. Mater. Interfaces 2016, 8, 7854-7861. [CrossRef] [PubMed] 
30. Annohene, G.; Tepper, G.C. Low temperature formation of $\mathrm{CH} 3 \mathrm{NH} 3 \mathrm{PbI} 3$ perovskite films in supercritical carbon dioxide. J. Supercrit. Fluids 2019, 154, 104604. [CrossRef]

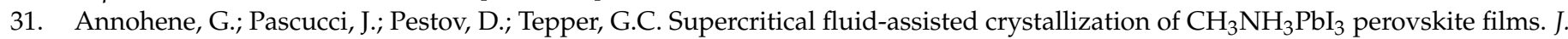
Supercrit. Fluids 2020, 156, 104684. [CrossRef]

32. Annohene, G.; Tepper, G.C. Efficient perovskite solar cells processed in supercritical carbon dioxide. J. Supercrit. Fluids 2021, 171, 105203. [CrossRef]

33. Rong, Y.; Hu, Y.; Mei, A.; Tan, H.; Saidaminov, M.I.; Seok, S.I.; McGehee, M.D.; Sargent, E.H.; Han, H. Challenges for commercializing perovskite solar cells. Science 2018, 361, eaat8235. [CrossRef] [PubMed]

34. Kang, J.; Han, K.; Sun, X.; Zhang, L.; Huang, R.; Ismail, I.; Wang, Z.; Ding, C.; Zha, W.; Li, F.; et al. Suppression of Ag migration by low-temperature sol-gel zinc oxide in the Ag nanowires transparent electrode-based flexible perovskite solar cells. Org. Electron. 2020, 82, 105714. [CrossRef]

35. Song, Z.; Abate, A.; Watthage, S.C.; Liyanage, G.K.; Phillips, A.B.; Steiner, U.; Graetzel, M.; Heben, M.J. Perovskite Solar Cell Stability in Humid Air: Partially Reversible Phase Transitions in the $\mathrm{PbI}_{2}-\mathrm{CH}_{3} \mathrm{NH}_{3} \mathrm{I}-\mathrm{H}_{2} \mathrm{O}$ System. Adv. Energy Mater. 2016, 6 , 1600846. [CrossRef]

36. Yang, J.; Siempelkamp, B.D.; Liu, D.; Kelly, T.L. Investigation of $\mathrm{CH}_{3} \mathrm{NH}_{3} \mathrm{PbI}_{3}$ Degradation Rates and Mechanisms in Controlled Humidity Environments Using in Situ Techniques. ACS Nano 2015, 9, 1955-1963. [CrossRef] [PubMed]

37. Bryant, D.; Aristidou, N.; Pont, S.; Sanchez-Molina, I.; Chotchunangatchaval, T.; Wheeler, S.; Durrant, J.R.; Haque, S.A. Light and oxygen induced degradation limits the operational stability of methylammonium lead triiodide perovskite solar cells. Energy Environ. Sci. 2016, 9, 1655-1660. [CrossRef]

38. Yang, T.; Jeon, N.J.; Shin, H.; Shin, S.S.; Kim, Y.Y.; Seo, J. Achieving Long-Term Operational Stability of Perovskite Solar Cells with a Stabilized Efficiency Exceeding 20\% after 1000 h. Adv. Sci. 2019, 6, 1900528. [CrossRef]

39. Conings, B.; Drijkoningen, J.; Gauquelin, N.; Babayigit, A.; D’Haen, J.; D’Olieslaeger, L.; Ethirajan, A.; Verbeeck, J.; Manca, J.; Mosconi, E.; et al. Intrinsic Thermal Instability of Methylammonium Lead Trihalide Perovskite. Adv. Energy Mater. 2015, 5, 1500477. [CrossRef]

40. Leijtens, T.; Eperon, G.; Pathak, S.; Abate, A.; Lee, M.M.; Snaith, H. Overcoming ultraviolet light instability of sensitized TiO 2 with meso-superstructured organometal tri-halide perovskite solar cells. Nat. Commun. 2013, 4, 2885. [CrossRef]

41. Shlenskaya, N.N.; Belich, N.A.; Grätzel, M.; Goodilin, E.A.; Tarasov, A.B. Light-induced reactivity of gold and hybrid perovskite as a new possible degradation mechanism in perovskite solar cells. J. Mater. Chem. A 2018, 6, 1780-1786. [CrossRef]

42. Zhou, Y.; Yin, Y.; Zuo, X.; Wang, L.; Li, T.-D.; Zhou, Y.; Padture, N.P.; Yang, Z.; Guo, Y.; Xue, Y.; et al. Enhancing Chemical Stability and Suppressing Ion Migration in $\mathrm{CH}_{3} \mathrm{NH}_{3} \mathrm{PbI}_{3}$ Perovskite Solar Cells via Direct Backbone Attachment of Polyesters on Grain Boundaries. Chem. Mater. 2020, 32, 5104-5117. [CrossRef]

43. Tan, S.; Yavuz, I.; De Marco, N.; Huang, T.; Lee, S.; Choi, C.S.; Wang, M.; Nuryyeva, S.; Wang, R.; Zhao, Y.; et al. Steric Impediment of Ion Migration Contributes to Improved Operational Stability of Perovskite Solar Cells. Adv. Mater. 2020, 32, 1906995. [CrossRef] [PubMed]

44. Noh, J.H.; Im, S.H.; Heo, J.H.; Mandal, T.N.; Seok, S.I. Chemical Management for Colorful, Efficient, and Stable Inorganic-Organic Hybrid Nanostructured Solar Cells. Nano Lett. 2013, 13, 1764-1769. [CrossRef] [PubMed]

45. Li, Z.; Yang, M.; Park, J.-S.; Wei, S.-H.; Berry, J.J.; Zhu, K. Stabilizing Perovskite Structures by Tuning Tolerance Factor: Formation of Formamidinium and Cesium Lead Iodide Solid-State Alloys. Chem. Mater. 2016, 28, 284-292. [CrossRef]

46. Saliba, M.; Matsui, T.; Seo, J.-Y.; Domanski, K.; Correa-Baena, J.-P.; Nazeeruddin, M.K.; Zakeeruddin, S.M.; Tress, W.; Abate, A.; Hagfeldt, A.; et al. Cesium-containing triple cation perovskite solar cells: Improved stability, reproducibility and high efficiency. Energy Environ. Sci. 2016, 9, 1989-1997. [CrossRef] [PubMed]

47. Mao, L.; Stoumpos, C.; Kanatzidis, M.G. Two-Dimensional Hybrid Halide Perovskites: Principles and Promises. J. Am. Chem. Soc. 2019, 141, 1171-1190. [CrossRef] [PubMed]

48. Yan, J.; Qiu, W.; Wu, G.; Heremans, P.; Chen, H. Recent progress in 2D/quasi-2D layered metal halide perovskites for solar cells. J. Mater. Chem. A 2018, 6, 11063-11077. [CrossRef]

49. Li, Y.; Shi, J.; Zheng, J.; Bing, J.; Yuan, J.; Cho, Y.; Tang, S.; Zhang, M.; Yao, Y.; Lau, C.F.J.; et al. Acetic Acid Assisted Crystallization Strategy for High Efficiency and Long-Term Stable Perovskite Solar Cell. Adv. Sci. 2020, 7, 1903368. [CrossRef] [PubMed]

50. Han, T.-H.; Lee, J.-W.; Choi, C.; Tan, S.; Lee, C.; Zhao, Y.; Dai, Z.; De Marco, N.; Lee, S.-J.; Bae, S.-H.; et al. Perovskite-polymer composite cross-linker approach for highly-stable and efficient perovskite solar cells. Nat. Commun. 2019, 10, 520. [CrossRef]


Perovskite Solar Cells. J. Phys. Chem. C 2014, 118, 16995-17000. [CrossRef]

52. Arora, N.; Dar, M.I.; Hinderhofer, A.; Pellet, N.; Schreiber, F.; Zakeeruddin, S.M.; Grätzel, M. Perovskite solar cells with CuSCN hole extraction layers yield stabilized efficiencies greater than 20\%. Science 2017, 358, 768-771. [CrossRef] [PubMed]

53. Aftab, A.; Ahmad, I. A review of stability and progress in tin halide perovskite solar cell. Sol. Energy 2021, 216, 26-47. [CrossRef]

54. Rao, M.K.; Sangeetha, D.; Selvakumar, M.; Sudhakar, Y.; Mahesha, M. Review on persistent challenges of perovskite solar cells' stability. Sol. Energy 2021, 218, 469-491. [CrossRef]

55. Jeevaraj, M.; Sudhahar, S.; Kumar, M.K. Evolution of stability enhancement in organo-metallic halide perovskite photovoltaics-a review. Mater. Today Commun. 2021, 27, 102159. [CrossRef] 
56. Frost, J.M.; Butler, K.T.; Brivio, F.; Hendon, C.H.; van Schilfgaarde, M.; Walsh, A. Atomistic Origins of High-Performance in Hybrid Halide Perovskite Solar Cells. Nano Lett. 2014, 14, 2584-2590. [CrossRef]

57. Ahn, N.; Son, D.-Y.; Jang, I.-H.; Kang, S.M.; Choi, M.; Park, N.-G. Highly Reproducible Perovskite Solar Cells with Average Efficiency of $18.3 \%$ and Best Efficiency of 19.7\% Fabricated via Lewis Base Adduct of Lead(II) Iodide. J. Am. Chem. Soc. 2015, 137, 8696-8699. [CrossRef]

58. Burschka, J.; Pellet, N.; Moon, S.-J.; Humphry-Baker, R.; Gao, P.; Nazeeruddin, M.K.; Grätzel, M. Sequential deposition as a route to high-performance perovskite-sensitized solar cells. Nature 2013, 499, 316-319. [CrossRef] [PubMed]

59. Im, J.-H.; Jang, I.-H.; Pellet, N.; Grätzel, M.; Park, N.-G. Growth of $\mathrm{CH}_{3} \mathrm{NH}_{3} \mathrm{PbI}_{3}$ cuboids with controlled size for high-efficiency perovskite solar cells. Nat. Nanotechnol. 2014, 9, 927-932. [CrossRef]

60. Luo, J.; Qiu, R.Z.; Yang, Z.S.; Wang, Y.X.; Zhang, Q.F. Mechanism and effect of $\gamma$-butyrolactone solvent vapor post-annealing on the performance of a mesoporous perovskite solar cell. RSC Adv. 2018, 8, 724-731. [CrossRef]

61. Oku, T. Crystal Structures of CH3NH3PbI3 and Related Perovskite Compounds Used for Solar Cells. In Solar Cells-New Approaches and Reviews; IntechOpen: London, UK, 2015; pp. 78-98. [CrossRef]

62. Chen, Q.; Zhou, H.; Hong, Z.; Luo, S.; Duan, H.-S.; Wang, H.-H.; Liu, Y.; Li, G.; Yang, Y. Planar Heterojunction Perovskite Solar Cells via Vapor-Assisted Solution Process. J. Am. Chem. Soc. 2013, 136, 622-625. [CrossRef]

63. Yang, G.; Wang, C.; Lei, H.; Zheng, X.; Qin, P.; Xiong, L.; Zhao, X.; Yan, Y.; Fang, G. Interface engineering in planar perovskite solar cells: Energy level alignment, perovskite morphology control and high performance achievement. J. Mater. Chem. A 2016, 5, 1658-1666. [CrossRef]

64. Acuña, D.; Krishnan, B.; Shaji, S.; Sepúlveda, S.; Menchaca, J.L. Growth and properties of lead iodide thin films by spin coating. Bull. Mater. Sci. 2016, 39, 1453-1460. [CrossRef]

65. Shen, D.; Yu, X.; Cai, X.; Peng, M.; Ma, Y.; Su, X.; Xiao, L.; Zou, D. Understanding the solvent-assisted crystallization mechanism inherent in efficient organic-inorganic halide perovskite solar cells. J. Mater. Chem. A 2014, 2, 20454-20461. [CrossRef] 